\title{
Confocal microscopic study of rabbit and human corneal epithelia using two objectives with different numerical aperture
}

\author{
Estudo em microscopia confocal do epitélio corneano do coelho e do homem utilizando \\ objetivas com diferentes aberturas numéricas
}

Leonardo P. Werner ${ }^{(1)}$

Liliana Werner ${ }^{(2)}$

Mathias König' (3)

Jean-Marc Leg'eais ${ }^{(4)}$

Gilles Renard (5)

\section{SUMMARY}

Purpose: The prospective study compares the confocal microscopic images of the rabbit and human corneal epithelial layers obtained with two objectives having different numerical apertures (NA).

Methods: Ten rabbit eyes were enucleated and kept in place by a pneumatic support to ensure the best performance of each objective, with no disturbance due to eye movements. Five normal patients were selected after agreement. The rabbit eyes and those of the patients were all examined with slit lamp. Confocal microscopy (Tomey, Erlangen-Tennenlohe, Germany) was performed with Achroplan (Zeiss, Oberkochen, Germany) $40 x / N A=0.75$ and $63 x / N A=0.9$ objectives. Selected images of the corneal epithelium layers were evaluated qualitatively for the size, shape, light scattering, and reflection of the cells.

Results: The cells in the superficial corneal epithelium of rabbit and human eyes, before desquamation, produced a much brighter reflection than the surrounding cells. This was clearly seen only with the $63 x / N A$ $=0.9$ objective. The corneal epithelium subsegments of the rabbit eyes, like the basal cell layer or the intermediate cell layer (wing cells), were visible under the high numerical aperture $(63 \mathrm{x} / \mathrm{NA}=0.9)$ objective only. These layers, in the human eyes, were more clearly visible using the high numerical aperture objective.

Conclusion: An objective with a high numerical aperture and a high optical resolution provided an improved analysis to study all the layers of the rabbit and human corneal epithelium.

Keywords: Corneal epithelium; Confocal microscopy.

\section{INTRODUCTION}

The outermost layer of the human cornea, the corneal epithelium, consists of 5-6 layers of 3 different types of epithelial cells: 2-3 layers of superficial cells, 2-3 layers of intermediate cells (wing cells), and a single layer of collunar basal cells ${ }^{1-3}$. In other animals such as rabbits, this epithelium has a fewer number of layers, however keeping the same cell morphology and distribution ${ }^{4}$. The human corneal epithelium is specifically involved in ocular disorders such as epithelial basement membrane dystrophy ${ }^{5}$. In cases of corneal intraepithelial neoplasia (CIN), it is the only touched layer ${ }^{6}$. Thus, a device that allows inspection of the layers of the corneal epithelium in vivo has considerable clinical potential.

Confocal microscopy is a new technique that can provide high 
resolution, and high contrast images of tissues. It is noninvasive, and gives real time images of the tissues at high magnifications in vivo, allowing studies at the cellular level ${ }^{5,7,8}$. The theoretical optics involved in confocal microscopy have been described in detail by Wilson and Sheppard ${ }^{9}$. Critical parameters of the confocal microscope design that can be varied to produce optimum imaging for a given tissue include: pinhole size, percent light transmission of the disk, number of holes/disk and mechanical motor rotation rates (pinholebased systems) ${ }^{7,9}$. Scanning slit confocal microscopes based on an oscillating two-sided mirror that simultaneously scan and descan can also have the parameters varied to image a tissue $^{10}$. Another important element of confocal microscopy is the design of the objective lens. The $\mathrm{Z}$-axis resolution depends greatly on the numerical aperture (NA) of the objective, with the best axial and lateral resolution obtained with a more elevated NA ( 0.9 or higher) ${ }^{7}$. Studies have in general been performed using an objective as the water-immersion $40 \mathrm{x} / \mathrm{NA}=$ 0.75 objective (Tomey), considered as a standard. The layers of the cornea can be clearly seen with this kind of objective ${ }^{11,12}$. Wiegand et al. ${ }^{13}$ indicate that objectives with a higher NA provide better image of the corneal epithelium layers. But, as far as we are aware, no specific comparison of objectives with different NA in corneal epithelium has been published. To the device we dispose in our Department, another objective $(63 \mathrm{x} /$ $\mathrm{NA}=0.9)$ is now available. According to the manufacturer (Tomey), its use is indicated specially when high selectivity is required, as to observe the details of corneal layers ${ }^{8}$. Rabbit enucleated eyes may be a potential substract to verify the performance of the objectives, because eye movements can disturb the capture of the images from the epithelium. Also, their cornea is thinner and this requires higher resolution of the objective for compensation, not dependent on the confocal microscopic system utilized. The aim of our study was to compare the confocal images obtained from rabbit and human corneal epithelium, using the standard objective $(40 \mathrm{x} / \mathrm{NA}=$ $0.75)$ and the new one $(63 \mathrm{x} / \mathrm{NA}=0.9)$ with a higher NA.

\section{MATERIALS AND METHODS}

The eyes of 5 (10 eyes) pigmented rabbits weighing 2.0 $2.6 \mathrm{Kg}$ and of 5 normal patients (10 eyes) were examined by the same investigator (L.P.W.) in the Department of Ophthalmology, Hôtel-Dieu Hospital. The rabbits were cared for in accordance with ARVO resolutions. All patients gave their informed consent prior to the study. The rabbit and patients eyes were first examined using a 900 slit-lamp biomicroscope (Haag-Streit, Koeniz, Switzerland), to detect any corneal abnormalities. The corneas were photographed with a SI-6E slit-lamp camera (Topcon, Tokyo, Japan).

The rabbits were anesthetized by an intramuscular injection of flunitrazepam (Narcozep- $0.5 \mathrm{mg} / \mathrm{Kg}$ ) and sacrificed with an intracardiac injection of ketamine hydrochloride. The eyes were immediately enucleated and kept in place on the confocal microscope with a pneumatic support (artificial orbit) to verify the best performance of each objective, without eye movement. Topical anesthesia was performed with oxibuprocaine chlohydrate $0.4 \%$ (Novesine, MSD) in lower conjunctival fornix of each patient.

The real-time scanning slit confocal microscope used was the ConfoScan Model P4, Tomey, Erlangen-Tennenlohe, Germany. A drop of sodium hyaluronate $(10 \mathrm{mg} / \mathrm{ml}$ Healonid; Pharmacia, Piscataway, NJ) was placed on the tip of the microscope objective to serve as immersion fluid. Thus, the corneal epithelium was not touched during the examination, and the corneas were not flattened. The objectives used to assess the morphology, surface reflection, contour, and nuclei of the epithelium cells were Achroplan (Zeiss, Oberkochen, Germany) water immersion lenses, $40 \mathrm{x} / \mathrm{NA}=0.75$ with an working distance of $1.98 \mathrm{~mm}$, and $63 \mathrm{x} / \mathrm{NA}=0.9$ with an working distance of $1.45 \mathrm{~mm}$. The position of the objectives was adjusted to obtain tangential optical sections of the cornea (X, Y axes), and the Z-axis was controlled with a manual micrometer drive. Oblique sections were obtained whenever possible. No examination took more than 2 minutes to complete and the images were recorded on an SVO-9620 Video Cassette Recorder (Sony Japan). The examinations of the corneal epithelium included the followings steps:

1. Focusing on the basal cell layer; centering the objective to obtain maximum reflection and surface parallel sections; videotape started.

2. Retraction to image the superficial cell layers.

3 . Focus on the intermediate cell layers.

4. Return to the basal cell layer.

Selected images from the videotape were captured with a frame grabber and stored in a BMP format file. They were subsequently printed in a CHC-S545 video printer (Shinko, Japan). The images were not enhanced with computer software.

\section{RESULTS}

Slit-lamp examination in rabbit and human corneal epithelium showed no alteration. The follow descriptions summarize the confocal microscopic findings and the objectives used are shown in figure 1. In viewing confocal images, it is important to remember that the optical sections are taken through the front. We consider that the width on the $40 \mathrm{x} / \mathrm{NA}=0.75$ objective is about $320 \mu \mathrm{m}$ and about $200 \mu \mathrm{m}$ on the $63 \mathrm{x} / \mathrm{NA}=0.9$ objective.

\section{Rabbit corneal epithelium (figure 2, A-D)}

Normal superficial cells were flattened and had a polygonal mosaic appearance, with bright reflective nuclei with both objectives in all 10 eyes, but individual cells were more easily analyzed with the $63 \mathrm{x} / \mathrm{NA}=0.9$ objective.

The intermediate and basal cells layers in all eyes could be seen only with the $63 \mathrm{x} / \mathrm{NA}=0.9$ objective. The intermediate 


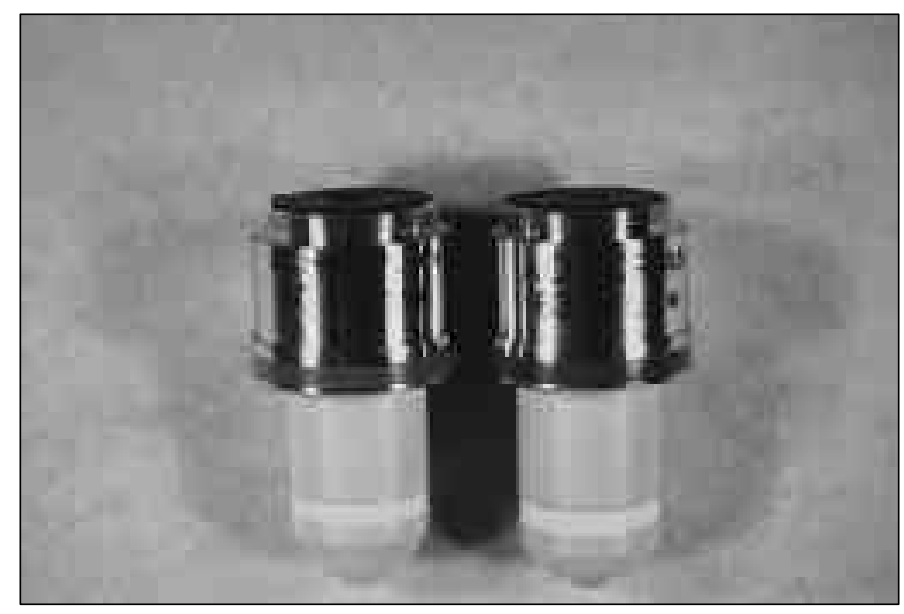

Figure 1. - The water-immersion objectives (40x/NA $=0.75$ and $63 \mathrm{x} / \mathrm{NA}$ $=0.90)$ used in the study

cells were polygonal with elongated reflective nuclei. The basal layer cells had bright outlines and their contents were dark, unlike the confocal microscope appearance of corneal endothelial cells, in which the cell outlines were dark and contents were bright.

\section{Human corneal epithelium (figure 3, A-F)}

Both objectives showed that the surfaces of all 10 eyes were covered by normal epithelium with a mosaic appearance. Superficial cells had highly reflective central nuclei. The cells were polygonal and the outlines were readily observed. However, individual cells were more easily analyzed with the $63 \mathrm{x} / \mathrm{NA}=0.9$ objective. The patterns varied from hexagonal to pentagonal and triangular cells. There were small dark areas in the focal plane with both objectives. Differences in cell reflection were clearer with the $63 \mathrm{x} / \mathrm{NA}=0.9$ objective (bright cells and dark cells). Cells presenting a similar light reflection tended to be grouped together and the reflex within any given cell was homogenous.

The $40 \mathrm{x} / \mathrm{NA}=0.75$ objective showed only the reflective nuclei in the intermediate cell layer lying over the basal cells in all 10 eyes. The cell outlines became visible at the higher magnification provided by the $63 \mathrm{x} / \mathrm{NA}=0.9$ objective.
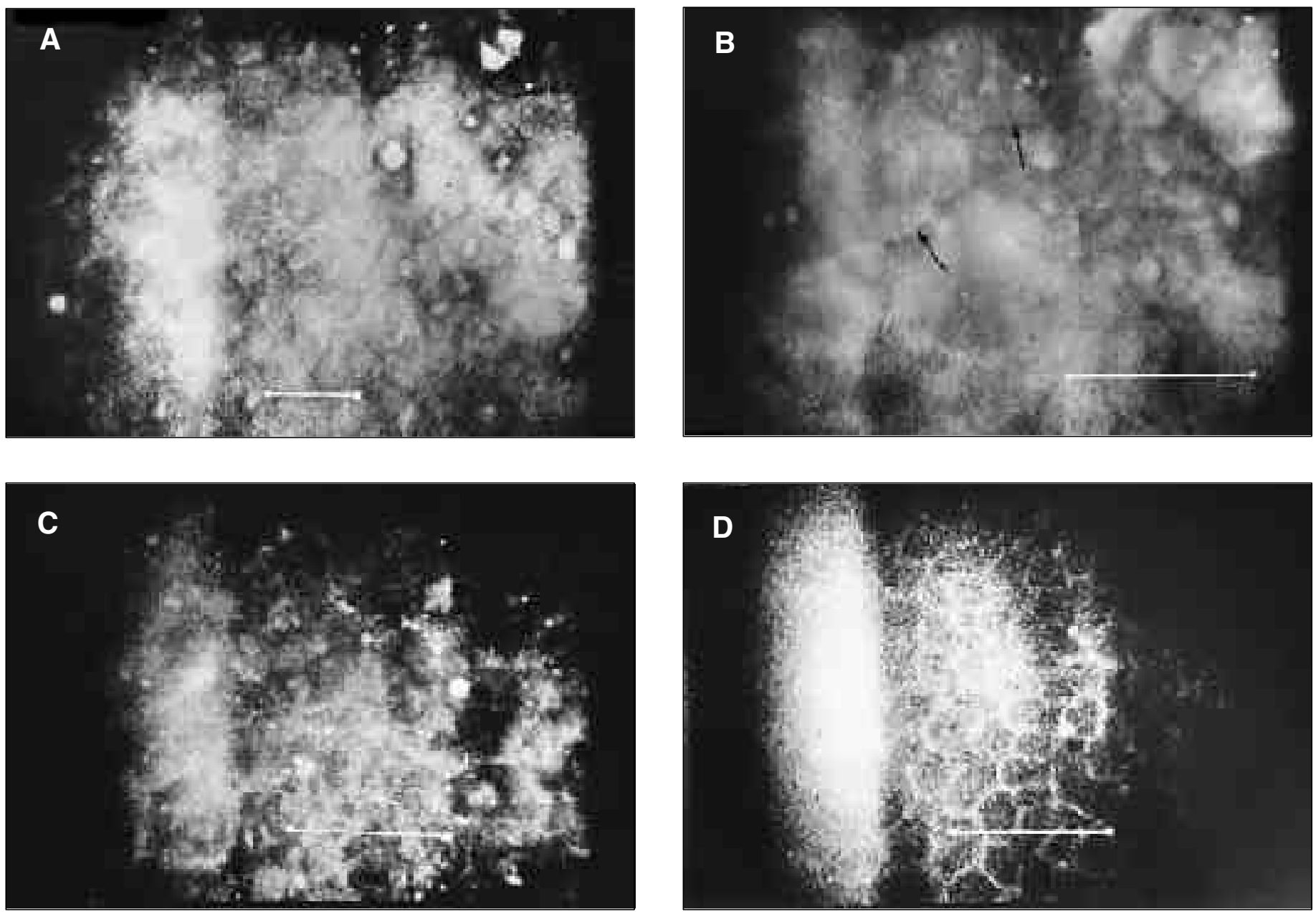

Figure 2 - Confocal microscope pictures of the normal rabbit corneal epithelium (bar $=50 \mu \mathrm{m})$. A: Superficial epithelial cells (40/0.75 objective). B: Same rabbit as in A. Individual cell outlines (arrows) are more easily seen (63/0.90 objective). C and D: Intermediate (C) and basal (D) cells are only observed with the $63 / 0.90$ objective. 
The basal epithelium cell layer was visible using both objectives, but individual cell outlines were clearer with the $63 \mathrm{x} / \mathrm{NA}=0.9$ objective. A white structure was occasionally visible in the cell center, suggestive of a cell nucleus.
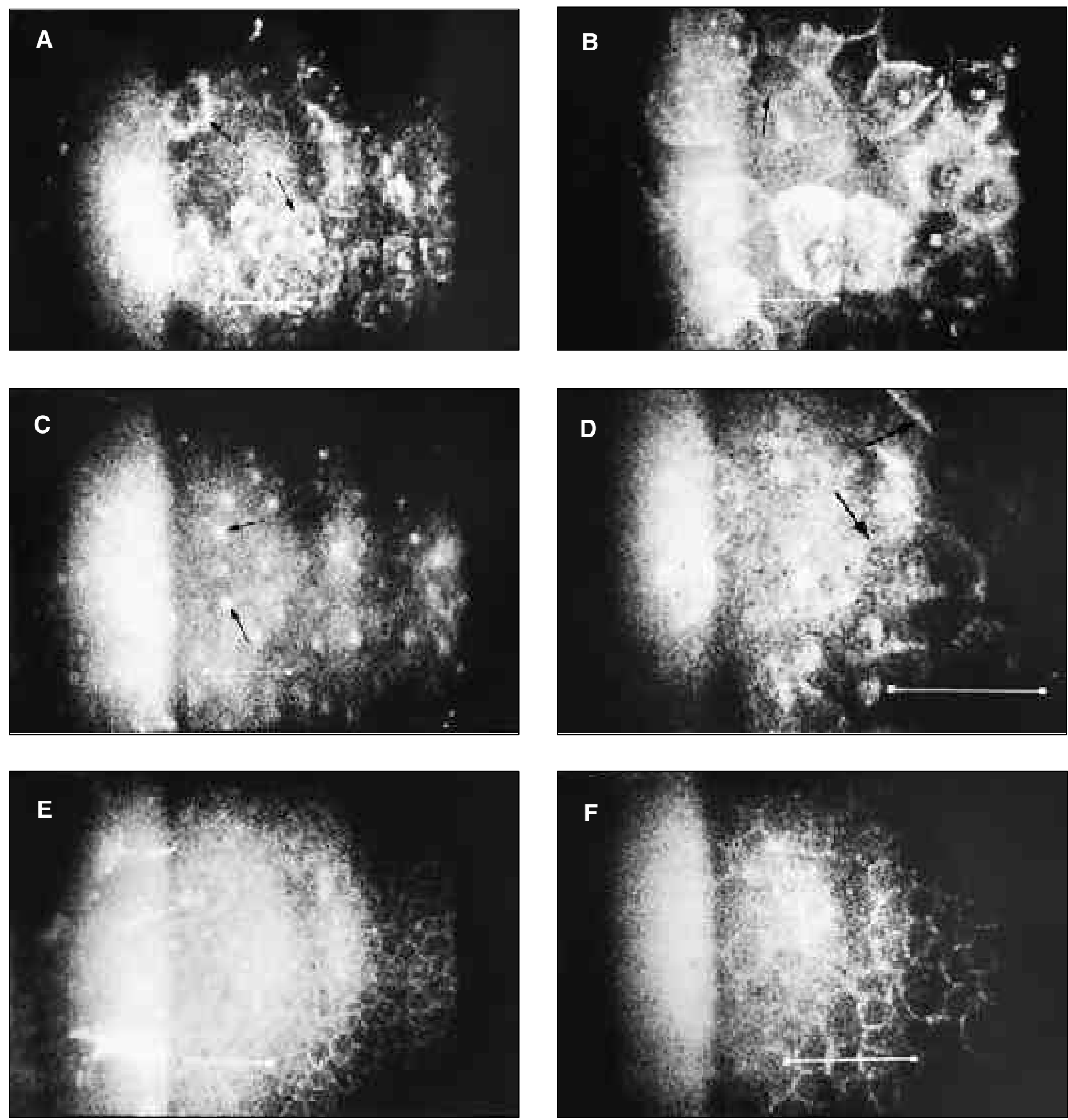

Figure 3 - Confocal microscope pictures of the normal human corneal epithelium (bar $=50 \mu \mathrm{m})$. A: Superficial epithelial cells (arrows) (40/0.75 objective) B: Same patient as in A. The small dark areas (arrow) suggest the peeling-off of mature cells from the superficial epithelium (63/0.90 objective). C: Nuclei (arrows) of the intermediate cells (40/0.75 objective). D: Same patient as in C. Cell outlines (arrows) in the intermediate epithelial layer can be observed with this objective (63/0.90). E: Basal cell layer (40/0.75 objective). F: Same patient as in E. The basal cell layer seen with the $63 / 0.90$ objective. 
a special plastic cone objective lens. This technique could be used to examine the epithelium in vivo, but the presence of tears between the specular contact lens and the cornea affected the quality of photographs. Although many improvements have been made since then, only the superficial layer of the epithelium (superficial cells) can be observed with the specular microscope, because there are no appreciable differences in refractive index within the normal corneal epithelium ${ }^{3}$.

Confocal microscopy is a noninvasive method that provides optical sections of the whole corneal tissue, and is thus a significant advance over specular microscopy ${ }^{12,15}$. In ocular tissues, Lemp et al. ${ }^{12}$ first used confocal microscopy to assess the details of the cells in all the corneal layers in excised human eyes and in rabbit eyes in situ. Many studies using confocal microscopy have since documented the appearance of normal and disease corneas ${ }^{16-21}$. Two previous studies were performed in our Department of Ophthalmology, Hôtel-Dieu Hospital, to assess the morphology of cystic disorders of the corneal epithelium and stromal corneal dystrophies ${ }^{5,8}$. The real time confocal microscope described in this paper required no analog or digital enhancements for producing the image quality shown in the micrographs of single video frames. The images obtained demonstrated the ability of this tool to assess the normal corneal epithelium. None of the micrographs showed any loss of contrast or were blurred, because the short exposure time reduced the percentage of low-quality images to $5 \%$ or less, (i.e., approximately $1 / 20$ frames/second). Our findings are comparable to histological sections of rabbit and human corneal epithelium.

The majority of the studies on the corneal epithelium have generally been done with standard objectives. Cavanagh et al. ${ }^{7}$ have described the appearance of normal superficial epithelium under the confocal microscope using a $20 \mathrm{x} / \mathrm{NA}=0.38$ objective. Ichijima et al. ${ }^{21}$ observed the deleterious effects of prolonged wearing of rigid gas permeable contact lenses on superficial corneal epithelia of rabbit eyes with a $24 \mathrm{x} / \mathrm{NA}=0.6$ objective. Our first study on the corneal epithelium assessed cystic disorders using the $40 \mathrm{x} / \mathrm{NA}=0.75$ objective $^{5}$. However, we believe that standard objectives showed only the more superficial lesions of the epithelium.

The clear advantage of the confocal microscope for ophthalmic diagnostics and basic eye research is best appreciated when the in vivo human basal and intermediate epithelium in the anterior cornea is imaged. Objectives lenses with a high NA ( 0.9 or higher) are required to obtain maximal lateral and axial resolution, contrast sensitivity, and optical sectioning in confocal optical systems ${ }^{7}$. Commercially available objectives with a high NA usually have a short working distance (0-1.5 mm), which limits the depth of tissue penetration $^{8,18}$. The $63 \mathrm{x} / \mathrm{NA}=0.9$ objective, for instance, has a working distance of $1.43 \mathrm{~mm}$, but this does not prevent study of the cornea surface, including the epithelium subsegments.

Wiegand et al. ${ }^{13}$ have described the appearance of the normal cornea by confocal microscopy using 2 objectives $(25 \mathrm{x} / \mathrm{NA}=0.6$ and $50 \mathrm{x} / \mathrm{NA}=1.0)$. They concluded that only the high NA objective was suitable for examining corneal subsegments like the basal epithelial cell layer or the intermediate epithelial cell layer. Our findings are in agreement with this study, and the objective with a high NA was needed to visualize all the layers of the normal corneal epithelium. The basal and intermediate cell layers (wing cells) of the human corneas were more visible with the high NA $(63 \mathrm{x} / \mathrm{NA}=0.9)$ objective. The high rejection of stray light and narrow depth of field coupled with the high NA microscope objective results in the ability of the instrument to image these cell layers clearly in the live cornea.

In superficial corneal epithelium, the cells before desquamation gave a much brighter reflection than the surrounding cells, as described by Wiegand et al. This was clearly observed with the $63 \mathrm{x} / \mathrm{NA}=0.9$ objective. Using a specular microscope, Tsubota et al. ${ }^{3}$ demonstrated that almost one third of the cells in normal superficial epithelium are bright cells, but the exact proportion is difficult to determine. The small dark areas among the cells were interpreted by Ichijima et al. ${ }^{21}$ as being due to peeling-off of superficial cells during normal maturation. The basal and the intermediate cell layers of the rabbit corneas were visible only with the high NA objective. The anatomy of the rabbit eye differs markedly from that of the human eye. The cornea is thinner (0.3-0.4 mm), and the corneal intermediate region has fewer cell layers ${ }^{4,21}$. The thickness of the rabbit basal cell layer is probably below the resolution limit of the $40 \mathrm{x} / \mathrm{NA}=0.75$ objective.

Imaging the corneas of conscious human subjects raised several specific problems. The main one is that the eye is constantly moving, even when looking at a fixed point. Involuntary flicks readjust the eye fixation and these constant involuntary movements blur images. Dipping applanating cone objectives, originally described by Laing et al. ${ }^{11}$ and Koester ${ }^{10}$, have been used to minimize eye movements. Moller-Pedersen et al. ${ }^{18}$ developed an improved eye fixation device (Haag-Streit, Waldwick, NJ) to reduce eye movements and to facilitate precise alignment of the objective to the visual axis. We used non-contact water-immersion objectives and a small light-point target to fix the eyes. The best images of the intermediate cells with the $63 \mathrm{x} / \mathrm{NA}=0.9$ objective were obtained in the period between 30-60 seconds of the examination. The initial 30 seconds were needed to focus on the epithelium and eliminate the surface reflection noise produced by the immersion technique. Eye movements increased after the first minute and the images were no longer high-quality. The $40 \mathrm{x} / \mathrm{NA}=0.75$ objective gave the best images during the first 40 seconds of the examination, as described by Hernández-Quintela et al. ${ }^{5}$ This objective clearly showed only the superficial and basal cell layers. The intermediate cell nuclei over the basal cell layer were occasionally visible.

The enucleated rabbit eyes kept in place with a pneumatic support gave no blurred images during the examination with either objective. Because of this, the best performances of 
both objectives were well documented with no disturbance due to eye movements. We also found that higher illumination levels (approximately 100\%) were needed to obtain the better images of the intermediate cell layer with the $63 \mathrm{x} / \mathrm{NA}=0.9$ objective. It may be due to the reflectivity of these cells which present a low-contrast object for confocal microscopy. However, this stronger light would certainly disturb patients, as recorded by Prydal et al. ${ }^{1}$ in studies on the cornea and tear film by confocal microscopy.

Our findings therefore suggest that the $63 \mathrm{x} / \mathrm{NA}=0.9$ objective provides more detailed images of the epithelium layers of the human and rabbit corneas than the $40 \mathrm{x} / \mathrm{NA}=0.75$ objective. The higher NA provides enough lateral and axial resolution for the observation of the intermediate cells. However, it was difficult to observe these cells using the $63 \mathrm{x} /$ $\mathrm{NA}=0.9$ objective because of eye movements. This was partly offset by the short exposure times needed. We believe that an ideal confocal microscope objective for examining the epithelium is one with high NA and a concave applanating tip that fixes the corneal periphery without touching its center, so minimizing eye movements. This objective would also be able to assess details of the other corneal layers, as well as the epithelium, when used with movable internal lenses to vary the working distance. Our instrument is configured only for real-time confocal microscopy of the cornea. However, with the introduction of a confocal microscope objective with a longer free working distance, it would be possible, for instance, to image the in vivo human lens. The in vivo study of intraocular lenses in humans could also be performed to investigate the migration and adhesion of cells to their surfaces. Through the development of a newly designed objective with a longer free working distance, the possibility to visualize the retina at high magnifications in vivo may alter our views on the pathogenesis of some diseases, such as retinitis pigmentosa and other slowly developing hereditary degenerations, for which biopsy is not possible. These studies are under way on human subjects.

Finally, the observations of corneal epithelium microstructure obtained by confocal microscopy dynamically without any preparation or staining artifacts will provide information on the epithelial microanatomy and physiology. The ability of the confocal microscope to visualize this epithelium over time may revolutionize our concepts of corneal epithelial diseases. The $63 \mathrm{x} / \mathrm{NA}=0.9$ objective may be particularly useful for examining abnormalities of the corneal epithelium, helping for instance the diagnosis and monitoring of intraepithelial neoplasias. We are currently performing these studies and the results are intended to be reported.

\section{RESUMO}

Objetivo: Este estudo prospectivo compara as imagens de microscopia confocal do epitélio corneano do coelho e do homem, obtidas através de 2 objetivas com aberturas numéricas $(A N)$ diferentes.
Métodos: Dez olhos de coelhos foram enucleados e fixados através de um suporte pneumático para garantir o melhor desempenho de cada objetiva. Cinco pacientes normais foram selecionados após consentimento. Os olhos de coelhos e dos pacientes foram previamente examinados na lâmpada de fenda. O exame de microscopia confocal (Tomey, Erlangen-Tennenlohe, Alemanha) foi realizado com as objetivas Achroplan 40x/AN =0,75 e 63x/AN =0,9 (Zeiss, Oberkochen, Alemanha). Imagens selecionadas do epitélio corneano foram avaliadas qualitativamente com relação ao tamanho, forma e refletividade das células.

Resultados: As células no epitélio superficial dos coelhos e dos pacientes, previamente à descamação, tiveram uma refletividade maior que as células adjacentes. Este aspecto foi claramente observado somente com a objetiva $63 x / A N=$ 0,9. As camadas basal e intermediária do epitélio em coelhos foram visualizadas somente através desta objetiva. Estas camadas nos pacientes tornaram-se mais nitidas com a objetiva de abertura numérica maior $(63 x / A N=0,9)$.

Conclusão: Uma objetiva de abertura numérica elevada produz melhor resolução dos cortes ópticos, facilitando a análise das camadas do epitélio no coelho e no homem.

\section{Palavras-chave: Epitélio corneano; Microscopia confocal.}

\section{REFERENCES}

1. Prydal J, Dilly PN. In vivo confocal microscopy of the cornea and tear film. Scanning 1995;17:133-5.

2. Renard G, Montanez-Mendonza M, Savoldelli M, Pouliquen Y. Etude en microscopie à balayage de l'épithelium cornéen. J Fr Ophtalmol 1983;6:697-705.

3. Tsubota K. In vivo observation of the corneal epithelium. Scanning 1994; 5:295-9.

4. Imayasu M, Moriyama, T, Ichijima H, Ohashi J, Petroll WM, Jester JV, Cavanagh HD. The effects of daily wear of rigid gas permeable contact lenses treated with contact lens care solutions containing preservatives on the rabbit cornea. CLAO J 1994;20:183-8.

5. Hernández-Quintela E, Mayer F Dighiero P, Briat B, Savoldelli M, Legeais JM, Renard G. Confocal microscopy of cystic disorders of the corneal epithelium. Ophthalmology 1998;105:631-6.

6. Waring GO, Roth AM, Elkins MB. Clinical and pathologic description of 17 cases of corneal intraepithelial neoplasia. Am J Ophthalmol 1984;97:547-59.

7. Cavanagh HD, Jester JV, Essepian J, Shields W, Lemp MA. Confocal microscopy of the living eye. CLAO J 1990;16:65-73.

8. Werner LP, Werner L, Dighiero P, Legeais JM, Renard G. Confocal microscopy in Bowman and stromal corneal dystrophies. Ophthalmology 1999;106:1697-704.

9. Wilson T, Scheppard C. Theory and practice of scanning optical microscopy. London: Academic Press, 1984.

10. Koester CJ. Scanning mirror microscope with optical sectioning characteristics: applications in ophthalmology. Appl Opt 1980;19:1749-57.

11. Laing RA, Sandstrom MM, Leibowitz HM. In vivo photomicrography of the corneal endothelium. Arch Ophthalmol 1975;93:143-5.

12. Lemp MA, Dilly PN, Boyde A. Tandem scanning confocal microscopy of the full thickness cornea. Cornea 1985;4:205.

13. Wiegand W, Thaer AA, Kroll P, Geyer OC, Garcia AJ. Optical sectioning of the cornea with a new confocal in vivo slit-scanning videomicroscope. Ophthalmology 1995;102:568-75.

14. MacFarland JL, Laing R, Oak SS. Specular microscopy of corneal epithelium. Arch Ophthalmol 1983;101:451-4.

15. Winchester K, Mathers WD, Sutphin JE. Diagnosis of Aspergillus keratitis in vivo with confocal microscopy. Cornea 1997;16:27-31. 
16. Kaufman SC, Hamano H, Beuerman RW, Laird JA, Thompson HW. Transient corneal stromal and endothelial changes following soft contact lens wear: a study with confocal microscopy. CLAO J 1996;22:127-32.

17. Sutphin JE, Kantor AL, Mathers WD, Mehaffey MG. Evaluation of infectious crystalline keratitis with confocal microscopy in a case series. Cornea 1997;16:21-6.

18. Moller-Pedersen T, Vogel M, Li HF, Petroll WM, Cavanagh HD, Jester JV. Quantification of stromal thinning, epithelial thickness, and corneal haze after photorefractive keratectomy using in vivo confocal microscopy. Ophthalmology 1997;104:360-8.
20. Cohen RA, Chew SJ, Gebhardt BM, Beuerman RW, Kaufman HE, Kaufman SC. Confocal microscopy of corneal graft rejection. Cornea 1995; 14:467-72.

21. Florakis GJ, Moazami G, Schubert H, Koester CJ, Auran JD. Scanning slit confocal microscopy of fungal keratitis. Arch Ophthalmol 1997; 115:1461-3.

22. Ichijima H, Ohashi J, Petroll WM, Cavanagh HD. Morphological and biochemical evaluation for rigid gas permeable contact lens extended wear on rabbit corneal epithelium. CLAO J 1993;19:121-8.

\section{SIMAsp 2000 XXII SIMPÓSIO INTERNACIONAL MOACYR ÁLVARO Retina, Vítreo, Úvea, AIDS, Trauma e Laser}

\section{4 a 26 de Fevereiro de 2000 \\ Hotel Transamérica - Av. das Nações Unidas, 18.591 São Paulo, SP - Brasil}

Este é um convite do Departamento de Oftalmologia da UNIFESP/EPM para um programa diferente. Tudo foi preparado pensando em você! Veja os pontos principais:

- 10 convidados estrangeiros: Eugene de Juan Jr., Carmen Puliafito, George Williams, Edgar L. Thomas, Henry Kaplan, Martin Uram, Juan I. Verdaguer D., Arturo A. Alezzandrini Jr., Gustavo Piantoni e Rafael Cortez.

- 2 dias com 30 palestras internacionais - temas fascinantes

- 30 casos clínico-cirúrgicos discutidos pelos palestrantes nacionais e internacionais

- 7 cursos paralelos: cirurgia de catarata - cirurgia refrativa - novas perspectivas em glaucoma - trauma ocular - prevenção da cegueira por retinopatia diabética - tratamento da degeneração macular relacionada a idade com terapia fotodinâmica - wet-lab de membrana amniótica

- Entrega da Medalha Moacyr Álvaro ao Prof. Nassim Calixto e Homenagem por Contribuição Acadêmica ao Prof. Sérgio Cunha.

- 2 concursos de temas livres

- 1 concurso de anatomia patológica

- 1 concurso de fotografia de segmento posterior

- 3 prêmios com passagens para Academia Americana de Oftalmologia de 2000

- 2 prêmios de viagem para 2 pessoas por 1 semana no Transamérica Comandatuba

- Ampla exposição comercial com lançamentos da indústria oftalmológica

Aproveite essa oportunidade e faça sua inscrição já. Bem vindo ao XXIII Simpósio Internacional do Centro de Estudos de Oftalmologia Moacyr Álvaro - III SIMAsp 2000!

\section{Secretaria Executiva:}

JDE - Comunicação e Eventos

Alameda Santos, $705 \mathrm{Cj} .56-01419-001$ - São Paulo/SP

Tel.: (0xx1 1) 289-4301/251-5273 - Fax: (0xx11) 288-8157

e-mail: jdecomev@uol.com.br 